Review

\title{
Long-Term Failure Mechanisms of Thermal Barrier Coatings in Heavy-Duty Gas Turbines
}

\author{
Feng Xie ${ }^{1} \mathbb{D}$, Dingjun $\mathrm{Li}^{2}$ and Weixu Zhang ${ }^{1, *(\mathbb{D}}$ \\ 1 State Key Laboratory for Strength and Vibration of Mechanical Structures, Department of Engineering \\ Mechanics, School of Aerospace Engineering, Xi'an Jiaotong University, Xi'an 710049, China; \\ xiefeng@stu.xjtu.edu.cn \\ 2 State Key Laboratory of Long-Life High Temperature Materials, Dongfang Electric Corporation Dongfang \\ Turbine Co., LTD, Deyang 618000, China; lidingjun@mail.dfstw.com \\ * Correspondence: zhangwx@mail.xjtu.edu.cn
}

Received: 26 September 2020; Accepted: 19 October 2020; Published: 23 October 2020

check for updates

\begin{abstract}
Thermal barrier coatings serve as thermal insulation and antioxidants on the surfaces of hot components. Different from the frequent thermal cycles of aero-engines, a heavy-duty gas turbine experiences few thermal cycles and continuously operates with high-temperature gas over $8000 \mathrm{~h}$. Correspondingly, their failure mechanisms are different. The long-term failure mechanisms of the thermal barrier coatings in heavy-duty gas turbines are much more important. In this work, two long-term failure mechanisms are reviewed, i.e., oxidation and diffusion. It is illustrated that the growth of a uniform mixed oxide layer and element diffusion in thermal barrier coatings are responsible for the changes in mechanical performance and failures. Moreover, the oxidation of bond coat and the interdiffusion of alloy elements can affect the distribution of elements in thermal barrier coatings and then change the phase component. In addition, according to the results, it is suggested that suppressing the growth rate of uniform mixed oxide and oxygen diffusion can further prolong the service life of thermal barrier coatings.
\end{abstract}

Keywords: heavy-duty gas turbine; thermal barrier coatings; oxidation; diffusion; failure

\section{Introduction}

A heavy-duty gas turbine is an important device for power generation. Thermal barrier coatings (TBCs) serve as a thermal protection structure and protect the hot components in heavy-duty gas turbines [1]. TBCs are made up of a top ceramic coat (TC), intermediate metal bond coat (BC) and the underlying superalloy substrate. A layer of thermally grown oxide (TGO) forms between the TC and $\mathrm{BC}$ during the oxidation of TBCs [2,3]. Different from the frequent thermal cycling of aero-engines, a heavy-duty gas turbine continuously operates at high temperature over $8000 \mathrm{~h}[4,5]$, as shown in Figure 1, and the thermal stress, which mainly originates from the start and stop, is almost released by material creep in the long-term service [6,7]. Moreover, the inlet air of a heavy-duty gas turbine is filtrated and clean. Thus, the attack of calcium-magnesium-aluminum-silicate (CMAS) also almost cannot occur. Accordingly, the spalling of TBCs is mainly induced by oxidation and element diffusion during its long-term service. 


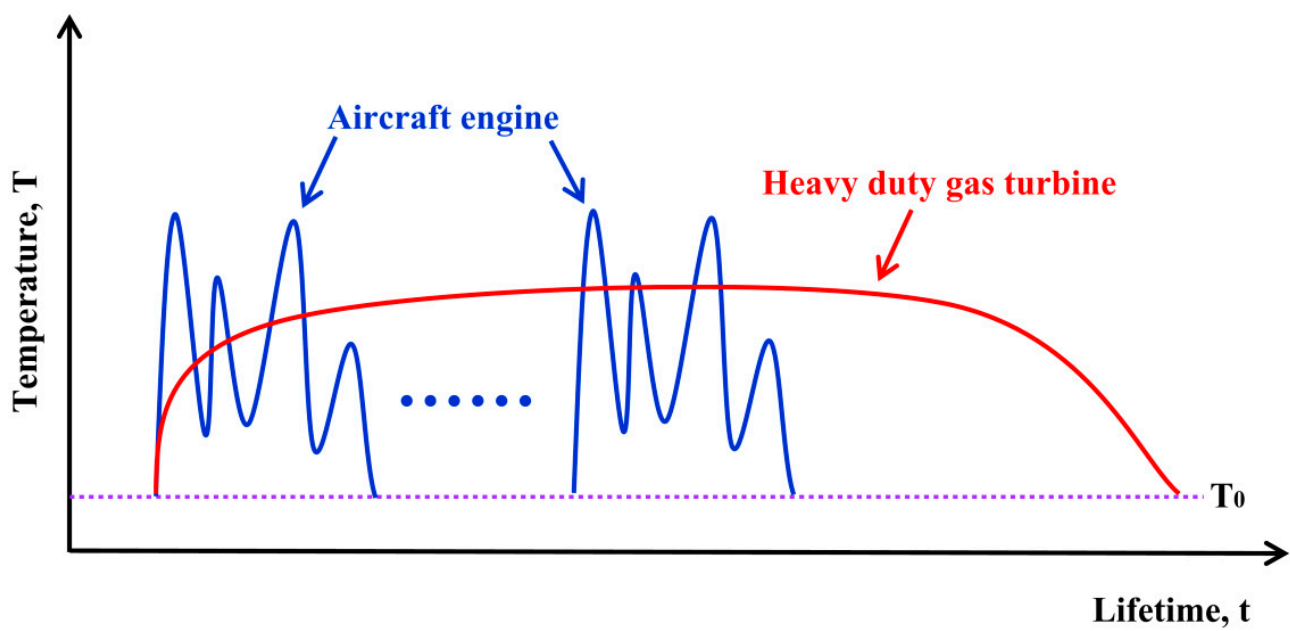

Figure 1. Schematic diagram of the typical service conditions of aero-engines and heavy-duty gas turbines. $T_{0}$ is the initial temperature.

Both oxidation and element diffusion involve long-term atomic exchange processes and exhibit the slow evolution behaviors of material. A typical BC composition is MCrAlY ( $\mathrm{M}=\mathrm{Ni}, \mathrm{Co}, \mathrm{NiCo})$ [8]. During the long-term oxidation of $\mathrm{TBC}$, firstly, $\mathrm{Al}$ in the $\mathrm{BC}$ reacts with the inward $\mathrm{O}$ and then slowly forms a dense $\alpha-\mathrm{Al}_{2} \mathrm{O}_{3}$. Then, with the continuous proceeding of oxidation, $\mathrm{Al}$ near the reaction region is almost depleted. While other alloy elements, e.g., $\mathrm{Ni}$ and $\mathrm{Co}$, continue to be oxidized, and the formed $\alpha-\mathrm{Al}_{2} \mathrm{O}_{3}$ is consumed through the reaction $\mathrm{Ni}+\mathrm{O}+\alpha-\mathrm{Al}_{2} \mathrm{O}_{3}=\mathrm{NiAl}_{2} \mathrm{O}_{4}$, accordingly the porous mixed oxide (MO), which comprises $\mathrm{NiO}, \mathrm{Cr}_{2} \mathrm{O}_{3}$ and $(\mathrm{Ni}, \mathrm{Co})\left(\mathrm{Cr}, \mathrm{Al}_{2} \mathrm{O}_{4}\right.$ [9], forms rapidly [10,11]. As a result, the mechanical performance of the $\mathrm{BC}$ changes significantly, which is detrimental for the reliability and durability of TBCs [12-14]. Thus, clarifying the long-term failure mechanism is helpful for us to evaluate the service performance and predict the lifetime of TBCs in heavy-duty gas turbines.

Generally, oxidation and element diffusion are a continuous and related process [2]. After TBCs operate at the elevated temperature, under the driving of the difference in chemical potential between the external reservoir, e.g., $\mathrm{O}_{2}$ and coating, the guest atoms, e.g., $\mathrm{O}$, leave the external reservoir and insert into coating at the boundary. Subsequently, the guest atoms continue to diffuse forwards in the coating until they reach the reaction region, as shown in Figure 2. When the guest atoms encounter the outward alloy elements, e.g., $\mathrm{Al}$ and $\mathrm{Ni}$, new oxides form and significant stress occurs due to the surrounding constraint. The induced stress not only causes the failures of TBCs but also affects the diffusion and oxidation processes. Thus, oxidation and diffusion, as a whole, are responsible for long-term failure mechanisms of TBCs in heavy-duty gas turbines.

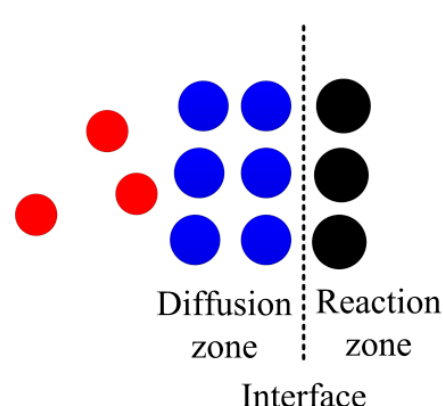

Interface
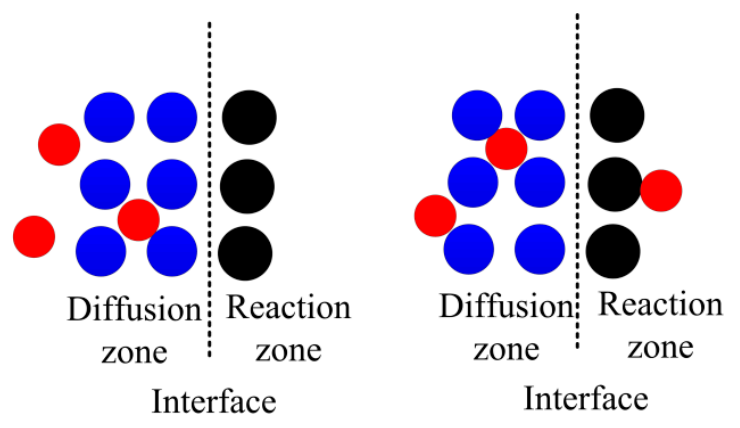

The guest atom The atom of diffusion zone The atom of reaction zone

Figure 2. Schematic diagram of oxidation and the diffusion of guest atoms in the long-time service process of thermal barrier coatings (TBCs) in heavy-duty gas turbines. 
Up to date, previous studies mainly focus on the fabrication, material, residual stress, cracking, sintering and thermal properties of TBCs [15-24]. For instance, Wang et al. [25] reviewed finite element method (FEM) research on thermal insulation, residual stress and the related failure problems of TBCs. Wang et al. [26] reviewed the research on the stress and crack problems in TBCs during the fabrication, oxidation, sintering and CMAS permeation. Lv et al. [27] also reviewed the FEM research on stress analysis, heat transfer as well as fracture and damage mechanisms in environment barrier coatings (EBCs). However, to our best knowledge, the long-term failure mechanism of TBCs still lacks attention, let alone a related review. For TBCs in heavy-duty gas turbines, the long-term oxidation and element diffusion are the dominant factors for its failure and change in performance. On one hand, the $\mathrm{BC}$ is continuously oxidized to form TGO, and the undulating TGO induces a tensile stress, which leads to the occurrence of cracks and interfacial delamination in TBCs. On the other hand, during the fabrication and service processes of TBCs, the diffusion of atoms, e.g., $\mathrm{O}$ and $\mathrm{Al}$, affects TGO growth [2] and forms interdiffusion zone [28]. When element diffusion is promoted, TGO grows fast and the interdiffusion zone enlarges. While creep cannot release the induced stress timely, accordingly, stress increases remarkably and then accelerates the failures of TBCs. Thus, it is necessary to review and analyze the related research on long-time oxidation and element diffusion.

To clarify the long-term failure mechanisms of TBCs in heavy-duty gas turbines, in this work, we review TGO growth and element diffusion, respectively. We analyze the continuous growth process of TGO and the coupled stress-diffusion process of elements. Finally, a conclusion that highlights the roles of MO growth and element diffusion in the failures of TBCs in heavy-duty gas turbines is made. Our results can provide some guide for improving the fabrication process and developing the long-life TBCs.

\section{Long-Term Oxidation of TBCs}

During the long-time service of heavy-duty gas turbines, thermal stress is almost released by material creep and then TGO growth becomes one important cause for failures of TBCs. Different from the short oxidation duration of aero-engines, TGO growth experiences a continuous change from $\alpha-\mathrm{Al}_{2} \mathrm{O}_{3}$ to $\mathrm{MO}$ stage during the long-term oxidation of TBCs in heavy-duty gas turbines. After improving and optimizing the fabrication process, the whole growth of uniform $\mathrm{MO}$ induces the large-scale spalling of TBCs, as shown in Figure 3. Thus, the continuous growth of TGO needs to be specially considered for the long-term failures of heavy-duty gas turbines.

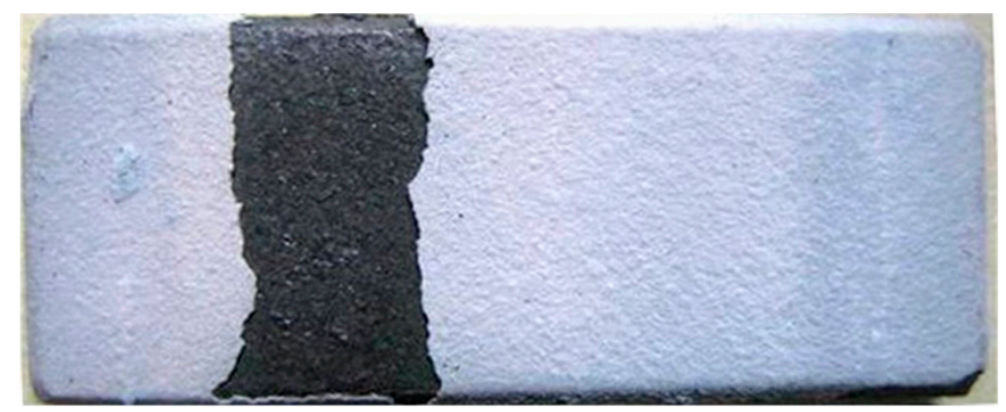

Figure 3. The large-scale spalling of TBCs after oxidizing for $500 \mathrm{~h}$ at $1100{ }^{\circ} \mathrm{C}$ [11].

\subsection{Research Advance on TGO Growth}

Until now, TGO growth and the related failures of TBCs have attracted increasing attention [29-34]. Experimental results show that TGO exhibits the undulating morphology and cracks mainly occur around the convex region [35-39]. Hutchinson et al. [40] and Evans et al. [41] investigated the buckling of the TGO layer induced by residual stress and established the critical criterion of buckling deformation. Mumm et al. [42] and He et al. [43] studied the displacement instability and the induced cracking of TBCs through a thermal cycling experiment and numerical simulation, respectively. The results 
revealed that the amplitude of the undulating TGO increases with the number of thermal cycling, which is also called ratcheting, and cracks initiate near TGO and gradually propagate. Moreover, Tolpygo and Clarke [44,45] found that the rumpling of oxide related to the grain orientation also affects the failures of TBCs. Su et al. [46] investigated the effect of TGO creep on the crack propagation in $\mathrm{TC}$, and the results show that with the increase of TGO creep, the driving force for crack propagation gradually decreases, and even after the TGO creep is strong enough, crack propagation is suppressed, as shown in Figure 4. In addition, other researchers [47-52] investigated the influence of undulating TGO morphology on residual stress in TBCs during thermal cycling. For instance, Chen et al. [53] adopted the finite element method to study the effects of different TGO asperities on residual stress in TBCs, and the obtained results show that the rougher TGO is, the more significant the residual tensile stress around the peak region is. The above research mainly focuses on the undulating TGO growth and the induced stress during thermal cycling. However, heavy-duty gas turbines experience few thermal cycles, and the continuous growth of TGO is a key factor in the failure of TBCs.

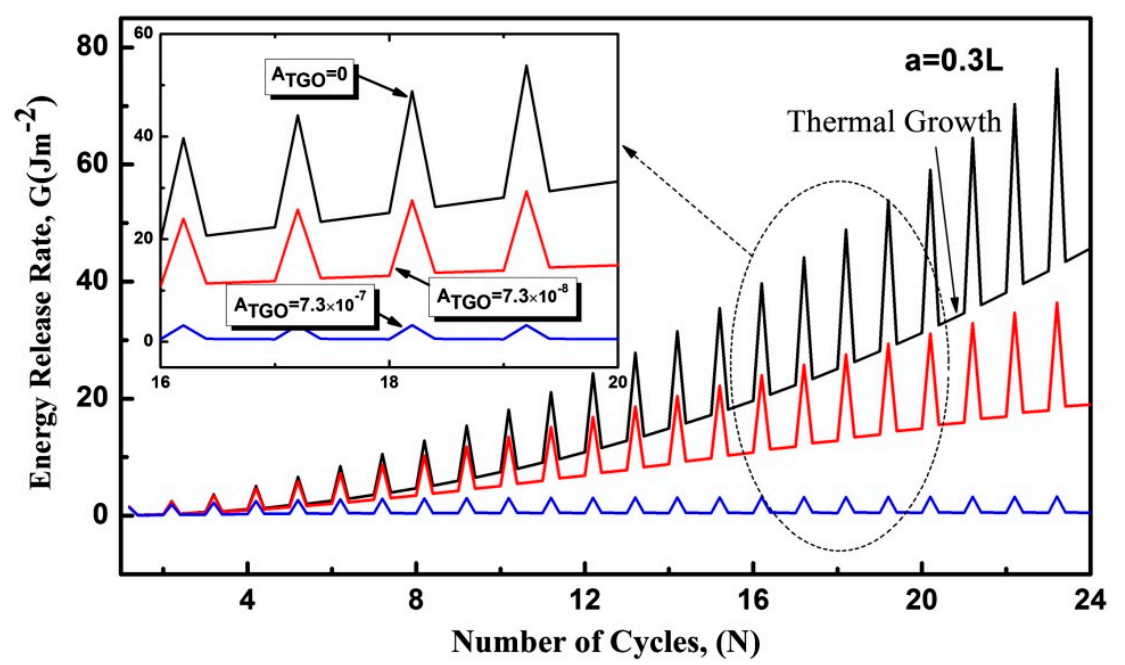

Figure 4. The variation of energy release rate with thermal cycling for different thermally grown oxide (TGO) creep [46].

Nowadays, many researchers focus on continuous TGO growth and the induced stress evolution in TBCs [54-60]. Evans et al. [61] utilized Eshelby's elastic inclusion method to make TGO growth equivalent to the self-assembly process of the free expansive TGO shell, and then established a sphere model of TGO growth. Clarke [62] investigated the lateral growth of TGO at the grain boundary and obtained a linear relationship between the lateral growth strain rate $\dot{\varepsilon}_{l}^{g}$ and the thickening rate $\dot{h}$, i.e., $\dot{\varepsilon}_{l}^{g}=D_{o x} \dot{h}$, where $D_{o x}$ is the scale coefficient related to the microstructure of oxide. Sun et al. [63] further set up a multilayer sphere model of the convex TBCs and considered TGO growth along with the thickness and in-plane directions, as shown in Figure 5a. The results showed that TGO growth generates the in-plane tensile stress in the TC, which can induce the occurrence of micro-cracks. Lin et al. [64] and Shen et al. [65] adopted the conception of oxidation front and considered the consumption of oxygen in the process of TGO growth, as shown in Figure 5b; the obtained results revealed that plasticity, creep and the irregular morphology of TGO affect the induced stress in TBCs. Moreover, TGO growth is more significant at the convex region relative to that at the concave region. Chai et al. [66] further investigated the stress development induced by "root-like" TGO growth, and the results showed maximum tensile stress changes from the interface to the inside of the BC. Loeffel et al. $[67,68]$ established a coupled constitutive theory of visco-plasticity, thermal expansion and volumetric deformation induced by chemical reaction, and numerically described the flat and undulating TGO growth through the finite element method. However, the above research mainly considers the growth of $\alpha-\mathrm{Al}_{2} \mathrm{O}_{3}$, which serves as the resistance to oxidation. Moreover, the induced 
stress can be almost released by creep during the long-term service. Thus, the obtained results are not applicable to the oxidation failures of TBCs in heavy-duty gas turbines.

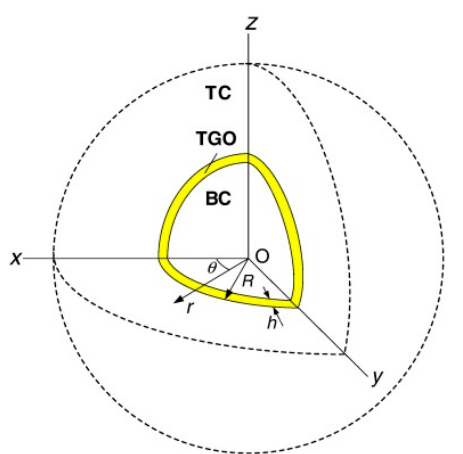

(a)

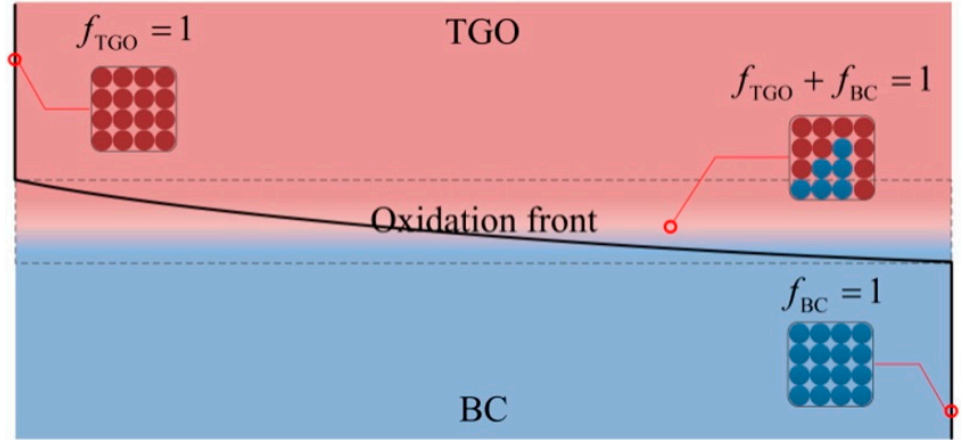

(b)

Figure 5. (a) The multilayer sphere model of TGO growth [63]; (b) the schematic diagram of oxidation front during the TGO growth [64].

Recently, much research shows that the growth of local MO induces the failures of TBCs after the oxidation for a period [69-71]. Busso et al. [72] investigated the effect of TGO growth around the convex region on the stress evolution in TBCs, and the results showed that the fast growth of non-protective oxide can enhance the development of stress. Li et al. [73] experimentally observed that the fast growth of local MO induces the cracking and interfacial delamination in the TC, as shown in Figure 6a. Zhang et al. [74] and Xu et al. [75] analytically and numerically model the growth of local $\mathrm{MO}$, respectively, as shown in Figure 6b; the results showed that the suppression of local MO growth can prolong the service life of TBCs. Moreover, Zhang et al. [76] healed the spattering particles through subsequent heat treatment and then eliminated the growth of local MO; the experiment results showed that, after healing, the lifetime of TBCs is further extended.

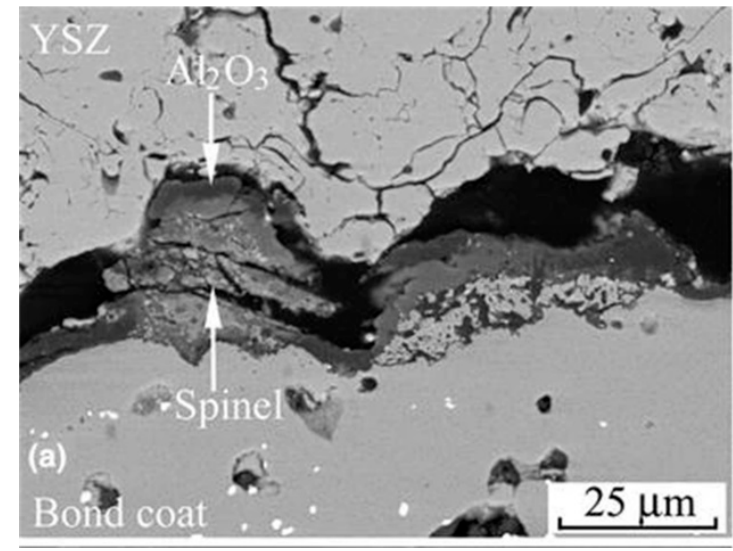

(a)
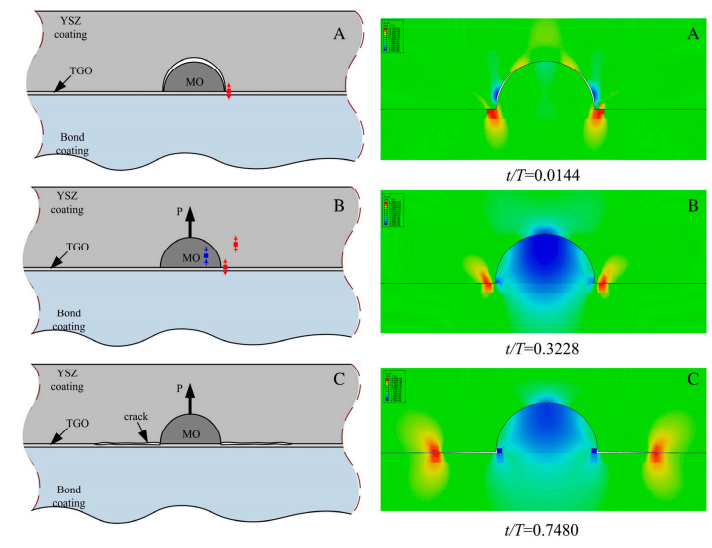

(b)

Figure 6. The local growth of mixed oxide (MO); (a) the local MO induces the failures of top ceramic coat (TC) [73]; (b) the numerical model and results of the local MO growth [75]; Among, the thermal expansion mismatch of $\mathrm{MO}$ and TC induces the interfacial tensile stress and debonding at stage $\mathrm{A}$, the growth of MO jacks TC up and induces the interfacial tensile stress at stage $\mathrm{B}$, and the growth of local $\mathrm{MO}$ induces the interfacial delamination at stage $\mathrm{C}$.

However, after local MO growth is suppressed, with the continuous proceeding of oxidation, cracking and interfacial delamination still occur in TBCs. Tang et al. [77] experimentally observed that after the composition of TGO changes from $\alpha-\mathrm{Al}_{2} \mathrm{O}_{3}$ to $\mathrm{MO}$, the delamination occurs at the $\alpha-\mathrm{Al}_{2} \mathrm{O}_{3} / \mathrm{MO}$ interface. Bai et al. [78] observed through the oxidation experiment of the CoNiCrAlY BC 
at $1100{ }^{\circ} \mathrm{C}$ that the whole growth of uniform MO still induces cracks in TBCs, as shown in Figure 7. Xie et al. [11] further modeled the whole growth of uniform MO and investigated the induced stress evolution, the obtained results revealed that the fast growth and large volumetric expansion of MO generate the catastrophic stress and then lead to the failures of TBCs. Lim and Meguid [79] adopted the coupled simulation of finite volume and finite element methods to numerically analyze the diffusion of $\mathrm{Cr}$ and $\mathrm{O}$. The results showed that even if the supply of $\mathrm{Al}$ is enough, the growth of $\mathrm{MO}$ still occurs. Mahalingam et al. [80] experimentally investigated the effects of the composition and the growth rate of TGO on crack propagation in TBCs. The results showed that the appearance of MO can lead to the fast propagation of the crack, which is consistent with Xie et al.'s calculation results [11].

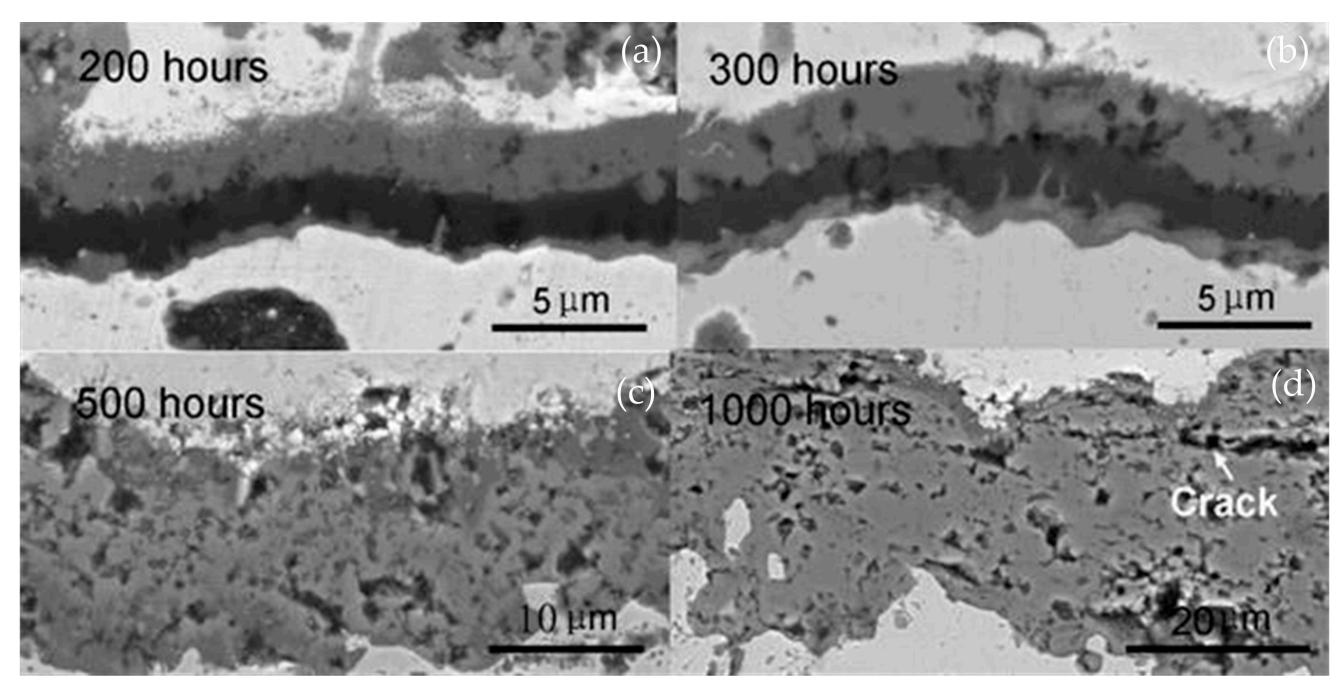

Figure 7. The oxidation results of CoNiCrAlY bond coat (BC) at $1100{ }^{\circ} \mathrm{C}$ for (a) $200 \mathrm{~h}$; (b) $300 \mathrm{~h}$; (c) $500 \mathrm{~h}$ and (d) $1000 \mathrm{~h}$ [78].

\subsection{Failure Mechanism of TBCs Induced by the Growth of Uniform MO}

Just as mentioned above, a heavy-duty gas turbine experiences few thermal cycles and is continuously exposed to a high temperature for a long time, thus the whole growth of uniform MO is the dominant oxidation result. During TGO growth, the resultant stress in TBCs depends on the competition between the stress generated by TGO growth and stress relaxation caused by creep. Compared to the $\alpha-\mathrm{Al}_{2} \mathrm{O}_{3}$ growth, MO grows much faster and expands more significantly, as shown in Figure 6; correspondingly, the induced stress is more remarkable. As material creep almost has no time to release the induced stress, stress in TBCs increases significantly and even changes from compressive stress to tensile stress, as shown in Figure 8. In addition, as $\alpha-\mathrm{Al}_{2} \mathrm{O}_{3}$ grows slowly, the induced stress is released by material creep significantly, thus, stress in TBCs is small and nearly compressive, which has been investigated by Sun et al. [63], and when TBCs experience few thermal cycles, the failures cannot occur.

During the growth of uniform $\mathrm{MO}$, the out-plane tensile stress at the $\alpha-\mathrm{Al}_{2} \mathrm{O}_{3} / \mathrm{MO}$ interface can induce the delamination and then lead to the spalling of TBCs. As the TC is pushed by the expansive $\mathrm{MO}$, the in-plane stress in the TC is also tensile, which can generate the cracks along with intersplat. Meanwhile, the in-plane tensile stress in $\alpha-\mathrm{Al}_{2} \mathrm{O}_{3}$ can lead to the occurrence of micro-cracks and then destroy its protective function. More $\mathrm{O}$ atoms and alloy elements diffuse along with the newly formed crack channel, and as a result, MO growth is further accelerated and even appears at the $\alpha-\mathrm{Al}_{2} \mathrm{O}_{3} / \mathrm{BC}$ interface, and spheroidization occurs around the crack, as shown in Figure 7. When MO grows faster, there is less time for creep to release the induced stress, thus the resultant stress in TBCs increases sharply, i.e., catastrophic stress develops. 


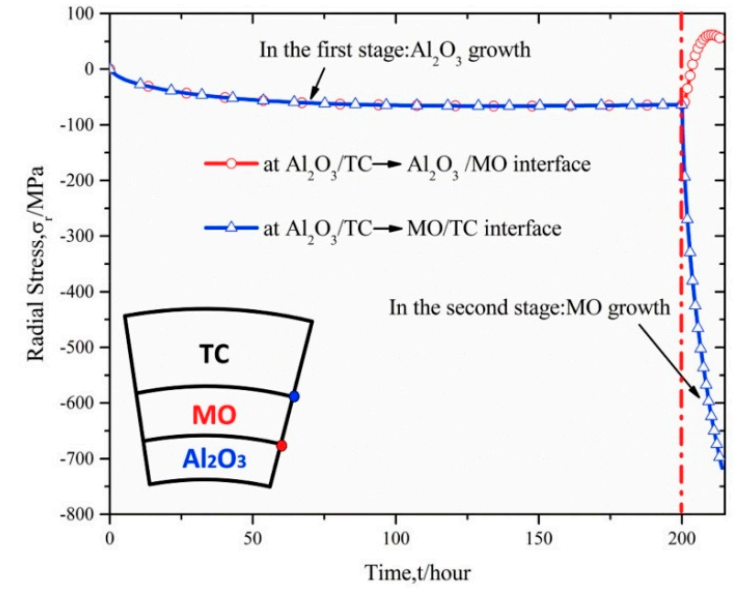

(a)

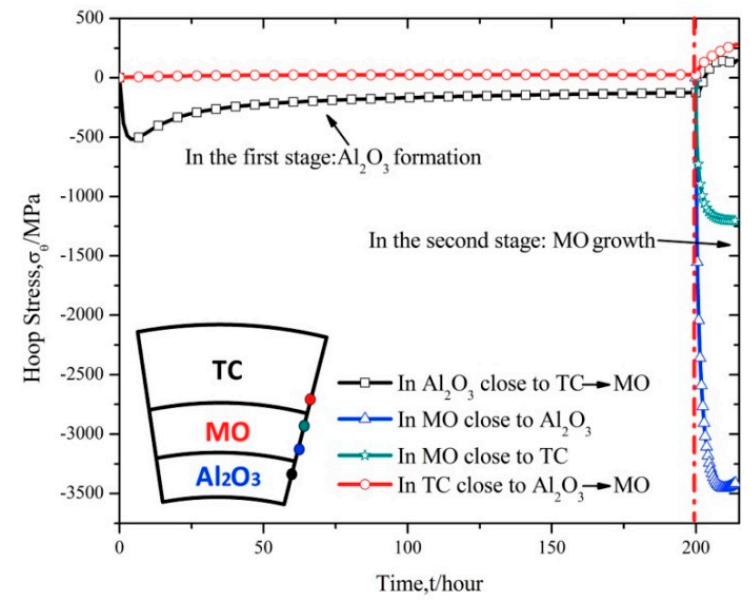

(b)

Figure 8. The stress evolution at the typical locations during the $\alpha-\mathrm{Al}_{2} \mathrm{O}_{3}$ and $\mathrm{MO}$ growth stages;

(a) radial stress; (b) hoop stress [11].

Different from the dense microstructure of $\alpha-\mathrm{Al}_{2} \mathrm{O}_{3}, \mathrm{MO}$ exhibits a porous microstructure and is brittle, accordingly, cracks and interfacial delamination are prone to occur there. Thus, the growth of uniform $\mathrm{MO}$ and the induced catastrophic stress are responsible for failures of TBCs in heavy-duty gas turbines, e.g., the cracks in $\alpha-\mathrm{Al}_{2} \mathrm{O}_{3}$ and TC layers, and the delamination at the $\alpha-\mathrm{Al}_{2} \mathrm{O}_{3} / \mathrm{MO}$ interface, as shown in Figure 9. According to the results, researchers can control the growth of uniform $\mathrm{MO}$ and suppress the diffusion of oxygen through improving material composition and fabrication processes to further prolong the service lifetime of TBCs.

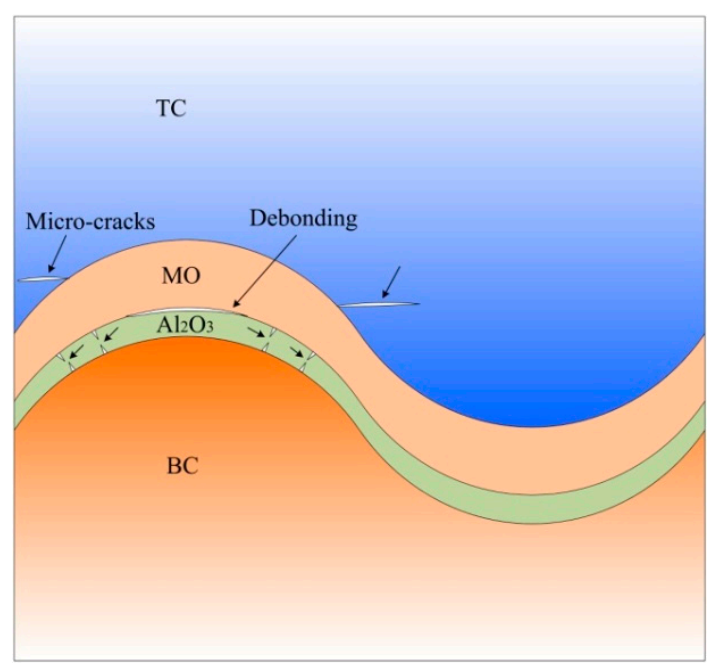

Figure 9. Schematic diagram of the failures induced by the growth of uniform MO in TBCs [11].

\section{Element Diffusion in TBCs}

Besides oxidation, element diffusion is also a key factor in the fabrication and long-term failures of TBCs. For instance, the diffusion of $\mathrm{Al}$ determines the performance of the as-sprayed NiAl bond coat in the alloying process of cold-sprayed $\mathrm{Ni} / \mathrm{Al}$ coating [81]. During the oxidation, the diffusion of $\mathrm{O}$ atom controls the growth of TGO [82], as shown in Figure 10a. Even the interdiffusion of alloy elements in the BC leads to the formation of Kirkendall voids at the interface [83], as shown in Figure 10b. These element diffusions directly affect the service performance of TBCs and need to be paid special attention. Herein, as the TC does not involve the element diffusion, it is neglected in the following. 


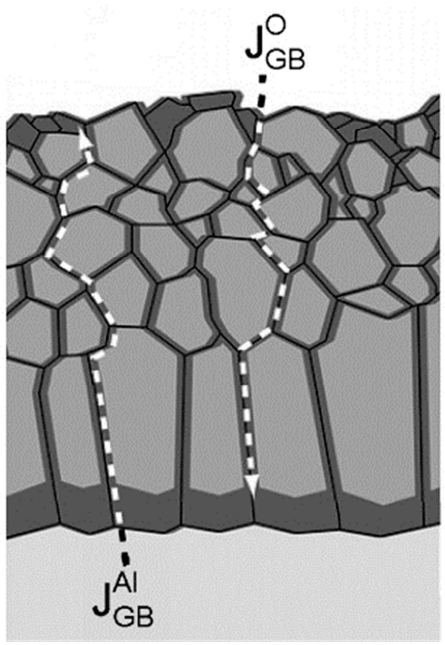

(a)

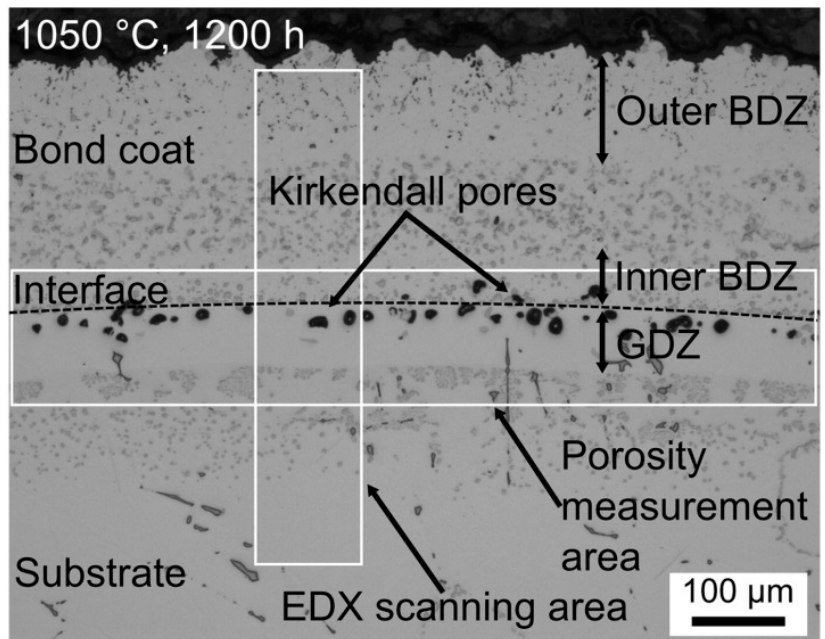

(b)

Figure 10. (a) The diffusion paths of $\mathrm{O}$ and $\mathrm{Al}$ atoms during the TGO growth [82]; (b) the interdiffusion of alloy element between BC and substrate [83].

\subsection{Research Progress on Diffusion}

Nowadays, element diffusion has attracted increasing attention [84]. First, Fick [85] investigated the diffusion from a high concentration to a low one, and obtained a linear relationship between flux $J$ and concentration gradient $\nabla C$, which is also called as "Fick's law", expressed as

$$
J=-D \nabla C
$$

where $D$ is diffusivity. Darken [86,87] further considered that the gradient of chemical potential is the driving force for diffusion, and the flux is approximatively related to the gradient of chemical potential $\nabla \mu$, expressed as

$$
J=-M C \nabla \mu
$$

where $M$ is the mobility of the atom, and satisfies the relationship $D=M R T$. Equation (2) can describe many diffusion phenomena, including the "uphill diffusion" which cannot be explained by Fick's law. When the chemical potential of atoms is only determined by their concentration, Equation (2) is the same as Fick's law, that is, the concentration gradient drives the diffusion of atoms.

However, element diffusion induces significant stress in TBCs and in turn affects the diffusion process. F.Q. Yang [88], Wang et al. [89], and Zhang et al. [90], respectively, investigated the effect of stress on diffusion in a plate, hollow cylinder as well as sphere model through considering the contribution of hydrostatic stress $\sigma_{m}$ to the chemical potential $\mu$, and the results revealed that stress promotes diffusion of atoms; here the expression of chemical potential can be written as

$$
\mu=\mu_{0}+R T \ln X-\Omega \sigma_{m}
$$

where $\mu_{0}$ is the reference, $R$ is gas constant, $T$ is the absolute temperature. $X$ is the fraction concentration, $\Omega$ is the partial molar volume and herein assumed to be constant. Moreover, Suo and Shen [91] considered the contribution of chemical reaction to element diffusion, expressed as

$$
\frac{\partial C}{\partial t}+\nabla \cdot J+\dot{r}=0
$$

where $\dot{r}$ is chemical reaction rate. Wang et al. [92] further investigated the transfer processes of $O$ and $\mathrm{Al}$ atoms during the concave TGO growth. 
Meanwhile, Haftbaradaran et al. [93] considered the effect of stress on the energy barrier of atomic jump during the diffusion and obtained a diffusivity with stress effect, expressed as

$$
D=D_{0} \exp \left(\frac{\alpha \Omega \sigma_{b}}{R T}\right)
$$

where $D_{0}$ is the pre-factor of diffusivity, $\alpha$ is positive dimensionless factor, and $\sigma_{b}$ is stress. Dong et al. [94] adopted the diffusivity with stress effect to investigate the influence of stress on the growth of metal oxide, the results showed that the induced stress slows down the thickening of oxide film through retarding the diffusion of oxygen. Fang et al. [95] further observed through a three-point bending experiment of $\mathrm{MoCu}$ alloy at $550{ }^{\circ} \mathrm{C}$ that the thickness of oxide film at the compressive region is significantly thinner than that at the tensile region, as shown in Figure 11. On the basis of the above research, we can see that stress significantly affects element diffusion through changing both the chemical potential and diffusivity. Whether stress accelerates diffusion or not depends on the actual service condition of TBCs.
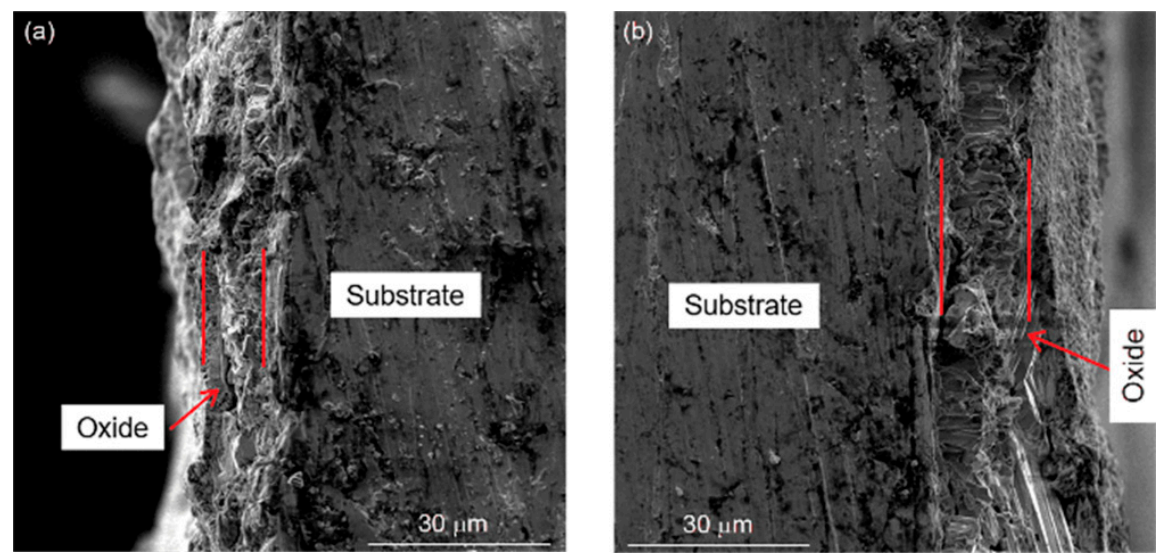

Figure 11. The three-point bending experiment results during the oxidation of $\mathrm{MoCu}$ alloy at $55^{\circ} \mathrm{C}$ [95]; (a) oxide film at the compressive region; (b) oxide film at the tensile region.

As a heavy-duty gas turbine operates at a high temperature for a long time, stress relaxation caused by creep is significant. Moreover, both creep and diffusion are the same time-scale atomic processes [96,97]. Thus, creep is the important stress relaxation mechanism along with element diffusion. Xie et al.'s [81] study revealed that the concentration of $\mathrm{Al}$ is low without stress relaxation during the alloying of Ni/Al coating. Sethuraman et al.'s $[98,99]$ experimental results further verify that stress relaxation exists in the process of diffusion and the relaxation behavior of stress is more in accordance with creep. Brassart and Suo [100] considered the flow deformation of solids induced by the insertion of guest atoms as reaction flow, and proposed the corresponding rate-dependent and -independent constitutive relationships. Meanwhile, many researchers [101-103] consider plasticity in the process of element diffusion. Zhao et al. [104,105] and Di Leo et al. [106] introduced plasticity to accommodate the large volumetric expansion induced by diffusion, and the results showed that plasticity releases the induced stress significantly. Other researchers [107-110] adopted elastic softening, i.e., elastic modulus changes with the concentration, to be responsible for stress relaxation during the diffusion. However, Chang et al.'s [111] work revealed that compared to the diffusivity, elastic softening is not the dominant factor in stress relaxation. In addition, Lu et al. [112] and Xu et al. [113] considered the stress relaxation induced by creep in a low-melting-point Sn electrode during Li diffusion, the results showed that creep can improve the durability of electrode. While for the element diffusion of TBCs in heavy-duty gas turbines, there still lacks the related research to clarify the role of creep.

Furthermore, interface property and residual stress also affect the element diffusion in TBCs. In the fabrication and service processes of TBCs, the surface of the $\mathrm{BC}$ is inevitably affected by the external 
reservoir, e.g., pre-oxidation, and then changes the interface property, as shown in Figure 12. Similarly, during the charging and discharging of Li-ion batteries, solid electrolyte interphase (SEI) forms at the surface of the electrode and then induces the capacity loss of the Li-ion battery [114]. In addition, sand blast, powder particle impact and quenching also generate residual stress in TBCs. The change of interface property and the generated residual stress can significantly affect the insertion of atoms at the boundary and the subsequent diffusion in TBCs. Zhang et al. [115] investigated the effect of the initial TGO thickness on its fracture contraction, the results showed that the thinner the initial TGO is, the easier the fracture contraction is. Xie et al. [81] modeled the alloying process of cold-sprayed Ni/Al coatings, and found that residual stress and interface property can significantly affect the diffusion of $\mathrm{Al}$ in the coating. However, the present research [116-119] mainly focuses on the improvement of interface property through adjusting the material composition and fabrication process. The effect of interface property on element diffusion in TBCs still lacks the related research.
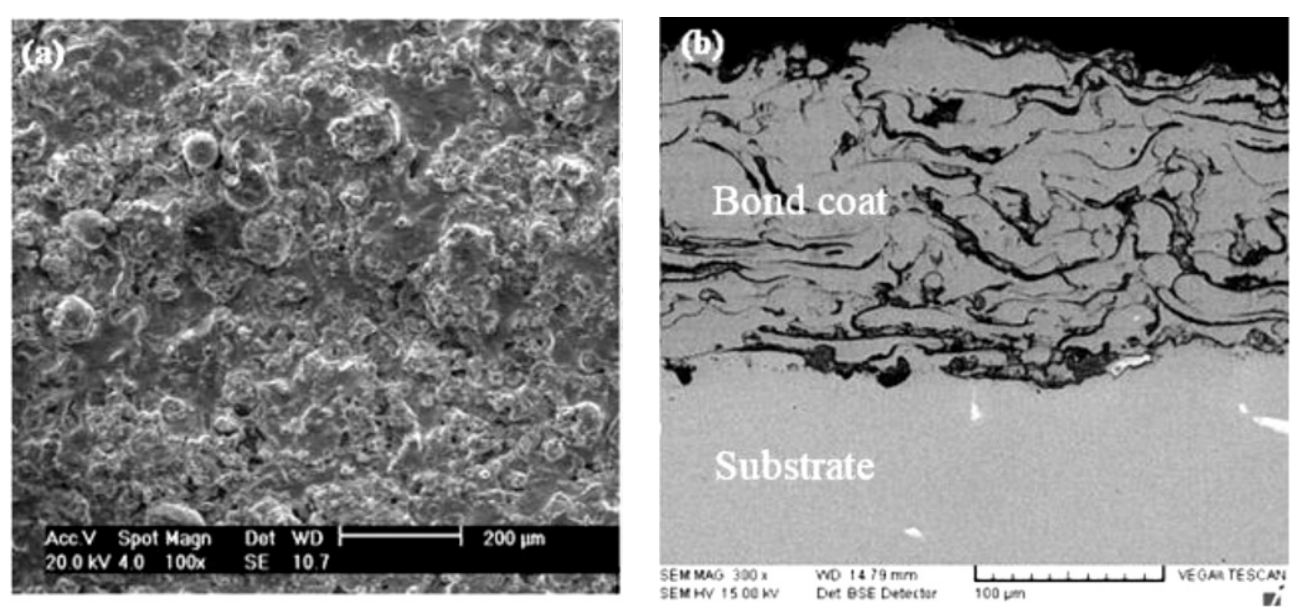

Figure 12. The micromorphology of pre-oxidized BC [120]. (a) The surface morphology of the as-sprayed BC; (b) the micro cross-section of the as-sprayed BC.

\subsection{Failure Mechanism of TBCs Related to Element Diffusion}

As a long-time evolution process, element diffusion is also closely related to the failures of TBCs in heavy-duty gas turbines [121-124]. Besides controlling TGO growth, element diffusion between the BC and substrate forms an interdiffusion region and changes the phase component [125]. The accumulation of vacancy near the interface leads to the appearance of Kirkendall voids [126] and then changes the interfacial strength, as shown in Figure 10b. Elsass et al. [83] investigated the effect of MCrAlY bond coat fabrication processes on the formation of Kirkendall voids, the results showed that compared to bond coats sprayed by high-velocity oxygen fuel (HVOF), bond coat fabricated by low pressure plasma spraying (LPPS) has the less Kirkendall voids during the oxidation, and the location of voids changes from bond coat to superalloy substrate. Texier et al. [127] carried out the micro-tensile experiment of the specimen taken from the interdiffusion region. The obtained results revealed that the existence of void decreases the mechanical property of the interdiffusion region. Qi et al. [128] investigated the cyclic oxidation behavior of $\beta$-NiAlHfCrSi coatings at $1150^{\circ} \mathrm{C}$, and found that the formation of voids under the oxide layer is the cause for its severe spalling. To evaluate the failures of TBCs induced by element diffusion, it is necessary to make clear the intrinsic mechanism of diffusion.

Herein, we take the alloying process of $\mathrm{Ni} / \mathrm{Al}$ coatings as a typical case to clarify the diffusion process of atoms. When diffusion starts, the $\mathrm{Al}$ atom firstly inserts into the $\mathrm{Ni}$ splat at the boundary. The insertion of $\mathrm{Al}$ induces significant compressive stress and increases the chemical potential. Accordingly, the difference in chemical potential between the external $\mathrm{Al}$ reservoir and Ni splat, which serves as the driving force for the insertion, is decreased. Thus, the supply of the $\mathrm{Al}$ atom gradually 
decreases until it vanishes, and then diffusion reaches equilibrium. During the insertion of $\mathrm{Al}$, the flux at the boundary can be written as

$$
J=-k\left(\mu-\mu^{\prime}\right)
$$

where $k$ is interfacial diffusivity and characterizes the interface property, and $\mu^{\prime}$ is the chemical potential of the external reservoir. When residual stress induced by cold spray is tensile, the chemical potential of $\mathrm{Al}$ is decreased, and then the flux at the boundary increases and the concentration of Al enlarges. Otherwise, the concentration of $\mathrm{Al}$ in $\mathrm{Ni}$ splat is decreased by residual compressive stress. Moreover, as shown in Figure 13, compared to the case without stress effect, the flux in the case with stress effect decreases more significantly. Thus, stress promotes the alloying but decreases the concentration of $\mathrm{Al}$, and the obtained quantitative relationship between the thickness of $\mathrm{Ni}$ splat and the alloying time significantly deviates from the common parabolic law. While the previous research [90] shows that stress accelerates the diffusion, the reason is that the flux at the boundary is kept as a constant. For element diffusion in TBCs, the common constant concentration or flux condition at the boundary is not applicable, and the flux at the boundary is affected by the induced stress and interface property.

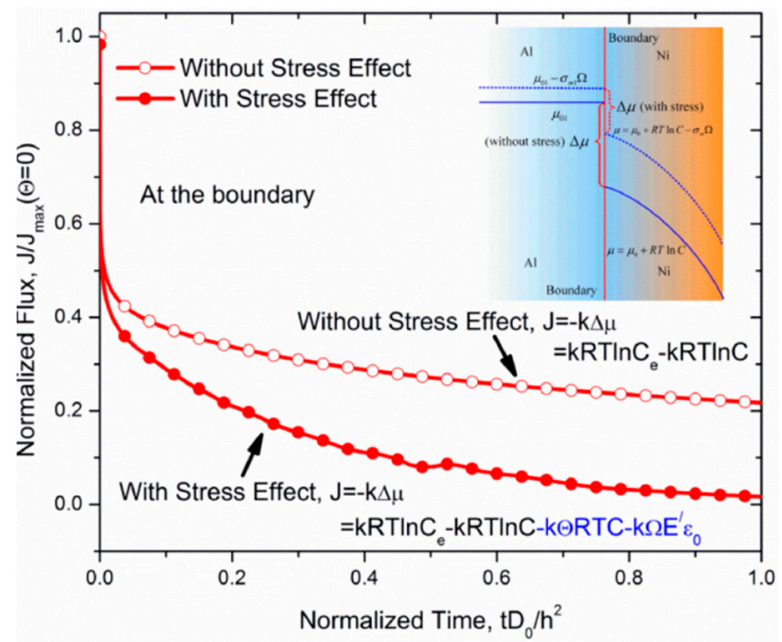

Figure 13. The fluxes at the boundary with and without stress effect, among which, $\varepsilon_{0}$ is the residual strain [81].

After the $\mathrm{Al}$ atom inserts into $\mathrm{Ni}$ splat, the large chemical potential gradient drives the $\mathrm{Al}$ atom to diffuse forwards in Ni splat, as shown in Figure 14a. The insertion of Al distorts the surrounding atomic network, and then induces significant stress. Meanwhile, the exchange of atoms can release the induced stress and creep occurs. Thus, the resultant stress depends on the competition between the stress generation by atomic insertion and stress relaxation by creep. The occurrence of stress not only affects the chemical potential but also changes the energy barrier of atomic jump, thus, both stress and its gradient affect the diffusion process. With the proceeding of diffusion, the chemical potential gradient in Ni splat gradually reduces until it vanishes, and then the alloying process completes and $\mathrm{Al}$ distributes uniformly, as shown in Figure 14b.

During the fabrication and operation of TBCs in heavy-duty gas turbines, element diffusion, creep as well as the induced stress affect the mechanical performance and service lifetime of TBCs. The change of phase component and the occurrence of Kirkendall voids and oxidation, which is closely related to element diffusion, determine the long-term failure patterns and mechanisms of TBCs. According to the results, researchers are encouraged to specially focus and control element diffusion in TBCs through adjusting material composition, imposing external force and developing new interface designs, etc. 


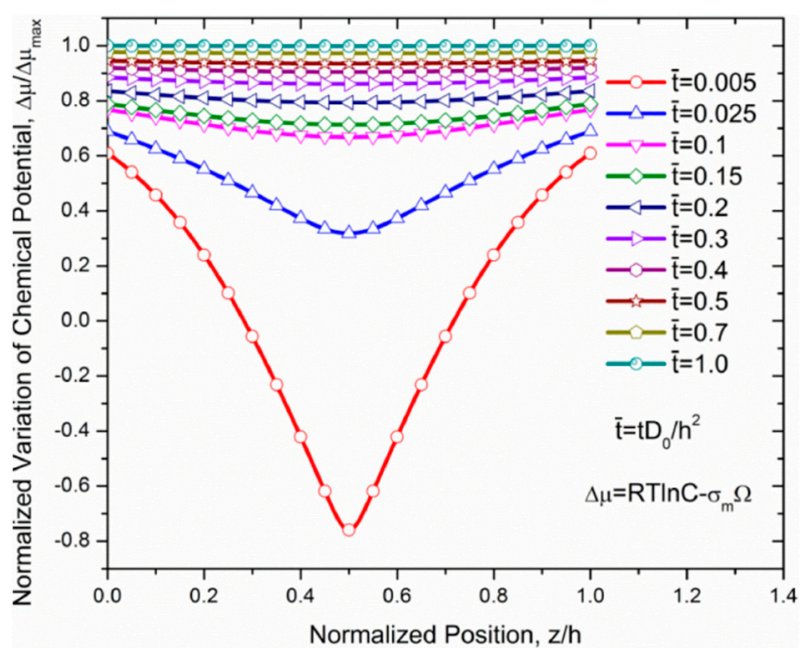

(a)

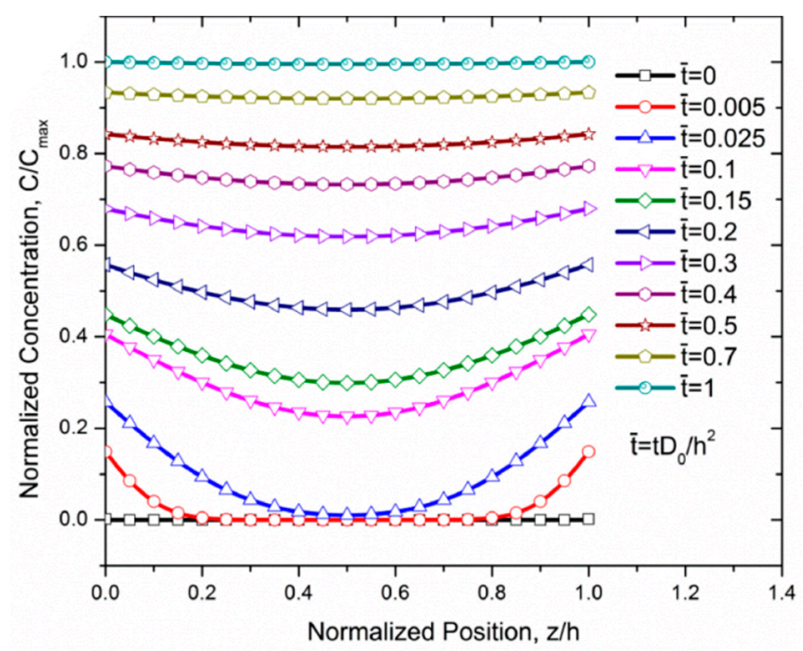

(b)

Figure 14. The diffusion of $\mathrm{Al}$ in $\mathrm{Ni}$ splat during the alloying of $\mathrm{Ni} / \mathrm{Al}$ coating [81]; (a) the distribution of the variation of chemical potential; (b) the distribution of concentration of Al. Note that in this work, stress relaxation and the change of the energy barrier of atomic jump are not considered.

\section{Summary}

Aiming to clarify the long-term failures of TBCs in heavy-duty gas turbines, in this work, the research on TGO growth and element diffusion are reviewed, which is mainly related to time effects. The failures of TBCs induced by the growth of uniform $\mathrm{MO}$ and the implied mechanism are summarized. The atomic process of element diffusion in TBCs and the induced change in performance are also analyzed. According to the results, the following conclusions are drawn:

a. Oxidation and element diffusion are responsible for the long-term failure mechanisms of TBCs. Different from the failures induced by the frequent thermal cycles in aero-engines, for heavy-duty gas turbines, the initial thermal stress can be almost released by material creep, and the long-time oxidation and element diffusion determine the change in performance and service lifetime of TBCs.

b. The catastrophic stress induced by the growth of uniform $\mathrm{MO}$ is a key cause for the long-term failure of TBCs. Compared to the slow growth of $\alpha-\mathrm{Al}_{2} \mathrm{O}_{3}$, the fast growth and large expansion of $\mathrm{MO}$ induce the out-plane tensile stress at the $\alpha-\mathrm{Al}_{2} \mathrm{O}_{3} / \mathrm{MO}$ interface and the in-plane tensile stress in $\alpha-\mathrm{Al}_{2} \mathrm{O}_{3}$ and TC layers. Accordingly, interfacial delamination and micro-cracks can appear in 
TBCs. Especially, once crack occurs in $\alpha-\mathrm{Al}_{2} \mathrm{O}_{3}$ layer, its protective function is destroyed, $\mathrm{MO}$ growth is further accelerated and then the lifetime of TBCs is reduced significantly.

c. The formations of an interdiffusion region and Kirkendall voids induced by element diffusion also play the key roles in the long-term failures of TBCs, besides controlling TGO growth. The process of element diffusion in TBCs is affected by stress, creep and interface property, etc. Moreover, the interdiffusion of alloy elements, surface oxidation of the BC and residual stress affect the distribution of element in TBCs, and then change the phase component, which leads to change in mechanical performance.

Our results provide an insight into the failures of TBCs in heavy-duty gas turbines and clarify the long-term failure mechanisms. We also suggest that controlling the growth rate of uniform MO, oxygen diffusion and interface property of the $\mathrm{BC}$ can further prolong the service life of TBCs. On the basis of results, researchers can develop long-life TBCs through adjusting material composition, improving the fabrication process and optimizing the structure design.

Author Contributions: Conceptualization, F.X. and W.Z.; investigation, F.X.; writing-original draft preparation, F.X.; writing-review and editing, F.X., D.L. and W.Z.; funding acquisition, W.Z. All authors have read and agreed to the published version of the manuscript.

Funding: This research was funded by National Natural Science Foundation of China (NSFC), grant No. 11972025, 11772246, 11472203, 11172227, in part by Program for New Century Excellent Talents in University, grant No. NCET-13-0466.

Acknowledgments: We thank Wang, T.J. for his helpful suggestion.

Conflicts of Interest: The authors declare no conflict of interest.

\section{References}

1. Clarke, D.R.; Oechsner, M.; Padture, N.P. Thermal-barrier coatings for more efficient gas-turbine engines. MRS Bull. 2012, 37, 891-902. [CrossRef]

2. Padture, N.P.; Gell, M.; Jordan, E.H. Materials science-Thermal barrier coatings for gas-turbine engine applications. Science 2002, 296, 280-284. [CrossRef]

3. Zhang, W.W.; Li, G.R.; Zhang, Q.; Yang, G.J. Comprehensive damage evaluation of localized spallation of thermal barrier coatings. J. Adv. Ceram. 2017, 6, 230-239. [CrossRef]

4. Zhou, J.H. The process management and fault treament of $9 \mathrm{~F}$ gas turbine during A-class maintenance. Intern. Combust. Engine Parts 2017, 60-62. (In Chinese)

5. Zeng, Z. The experience in formulating the repair cycle of gas turbine. Gas Turbine Technol. 2012, $25,68-72$. (In Chinese)

6. Rosler, J.; Baker, M.; Aufzug, K. A parametric study of the stress state of thermal barrier coatings-Part I: Creep relaxation. Acta Mater. 2004, 52, 4809-4817. [CrossRef]

7. Rosler, J.; Baker, M.; Volgmann, M. Stress state and failure mechanisms of thermal barrier coatings: Role of creep in thermally grown oxide. Acta Mater. 2001, 49, 3659-3670. [CrossRef]

8. Lee, C.H.; Kim, H.K.; Choi, H.S.; Ahn, H.S. Phase transformation and bond coat oxidation behavior of plasma-sprayed zirconia thermal barrier coating. Surf. Coat. Technol. 2000, 124, 1-12. [CrossRef]

9. Ali, M.S.; Song, S.H.; Xiao, P. Degradation of thermal barrier coatings due to thermal cycling up to 1150 degrees C. J. Mater. Sci. 2002, 37, 2097-2102. [CrossRef]

10. Ma, K.K.; Schoenung, J.M. Isothermal oxidation behavior of cryomilled NiCrAlY bond coat: Homogeneity and growth rate of TGO. Surf. Coat. Technol. 2011, 205, 5178-5185. [CrossRef]

11. Xie, F.; Sun, Y.L.; Li, D.J.; Bai, Y.; Zhang, W.X. Modelling of catastrophic stress development due to mixed oxide growth in thermal barrier coatings. Ceram. Int. 2019, 45, 11353-11361. [CrossRef]

12. Gupta, M.; Eriksson, R.; Sand, U.; Nylen, P. A diffusion-based oxide layer growth model using real interface roughness in thermal barrier coatings for lifetime assessment. Surf. Coat. Technol. 2015, 271, 181-191. [CrossRef] 
13. Soulignac, R.; Maurel, V.; Remy, L.; Koster, A. Cohesive zone modelling of thermal barrier coatings interfacial properties based on three-dimensional observations and mechanical testing. Surf. Coat. Technol. 2013, 237, 95-104. [CrossRef]

14. Fan, X.L.; Zhang, W.X.; Wang, T.J.; Sun, Q. The effect of thermally grown oxide on multiple surface cracking in air plasma sprayed thermal barrier coating system. Surf. Coat. Technol. 2012, 208, 7-13. [CrossRef]

15. Zhang, J.; Guo, X.Y.; Jung, Y.G.; Li, L.; Knapp, J. Lanthanum zirconate based thermal barrier coatings: A review. Surf. Coat. Technol. 2017, 323, 18-29. [CrossRef]

16. Thakare, J.G.; Pandey, C.; Mahapatra, M.M.; Mulik, R.S. Thermal barrier coatings-A state of the art review. Met. Mater. Int. 2020, 1-22. [CrossRef]

17. Liu, M.J.; Zhang, G.; Lu, Y.H.; Han, J.Q.; Li, G.R.; Li, C.X.; Li, C.J.; Yang, G.J. Plasma spray-physical vapor deposition toward advanced thermal barrier coatings: A review. Rare Met. 2020, 39, 479-497. [CrossRef]

18. Mehta, A.; Vasudev, H.; Singh, S. Recent developments in the designing of deposition of thermal barrier coatings-A review. Mater. Today Proc. 2020, 26, 1336-1342. [CrossRef]

19. Yang, X.; Zhang, J.; Lu, Z.; Park, H.Y.; Jung, Y.G.; Park, H.; Koo, D.D.; Sinatra, R.; Zhang, J. Removal and repair techniques for thermal barrier coatings: A review. Trans. IMF 2020, 98, 121-128. [CrossRef]

20. Zhou, Y.; Liu, Q.; Yang, L.; Wu, D.; Mao, W. Failure mechanisms and life prediction of thermal barrier coatings. Acta Mech. Solida Sin. 2010, 31, 504-531.

21. Miller, R.A. Current status of thermal barrier coatings-An overview. Surf. Coat. Technol. 1987, 30, 1-11. [CrossRef]

22. Vassen, R.; Jarligo, M.O.; Steinke, T.; Mack, D.E.; Stover, D. Overview on advanced thermal barrier coatings. Surf. Coat. Technol. 2010, 205, 938-942. [CrossRef]

23. Mehboob, G.; Liu, M.-J.; Xu, T.; Hussain, S.; Mehboob, G.; Tahir, A. A review on failure mechanism of thermal barrier coatings and strategies to extend their lifetime. Ceram. Int. 2020, 46, 8497-8521. [CrossRef]

24. Hu, Z.-C.; Liu, B.; Wang, L.; Cui, Y.-H.; Wang, Y.-W.; Ma, Y.-D.; Sun, W.-W.; Yang, Y. Research progress of failure mechanism of thermal barrier coatings at high temperature via finite element method. Coatings 2020, 10, 732. [CrossRef]

25. Wang, L.; Li, D.C.; Yang, J.S.; Shao, F.; Zhong, X.H.; Zhao, H.Y.; Yang, K.; Tao, S.Y.; Wang, Y. Modeling of thermal properties and failure of thermal barrier coatings with the use of finite element methods: A review. J. Eur. Ceram. Soc. 2016, 36, 1313-1331. [CrossRef]

26. Wang, T.; Fan, X.; Sun, Y.; Su, L.; Song, Y.; Lv, B. The stresses and cracks in thermal barrier coating system: A review. Chin. J. Solid Mech. 2016, 37, 477-517.

27. Lv, B.W.; Jin, X.C.; Cao, J.; Xu, B.S.; Wang, Y.G.; Fang, D.N. Advances in numerical modeling of environmental barrier coating systems for gas turbines. J. Eur. Ceram. Soc. 2020, 40, 3363-3379. [CrossRef]

28. Elsass, M.; Frommherz, M.; Oechsner, M. The Influence of the coating deposition process on the interdiffusion behavior between nickel-based superalloys and MCrAlY bond coats. J. Therm. Spray Technol. 2018, 27, 379-390. [CrossRef]

29. Wei, Z.Y.; Cai, H.N. Comprehensive effects of TGO growth on the stress characteristic and delamination mechanism in lamellar structured thermal barrier coatings. Ceram. Int. 2020, 46, 2220-2237. [CrossRef]

30. Chai, Y.J.; Lin, C.; Li, Y.M. Effects of creep-plastic behavior on stress development in TBCs during cooling. Ceram. Int. 2017, 43, 11627-11634. [CrossRef]

31. Yang, S.; Peng, H.; Zhang, T. A damage model to evaluate the mechanical properties in the medium-long life stage for coating system subjected to elevated thermal loads with 3D-DIC technique. J. Alloy. Compd. 2020, 832, 154955. [CrossRef]

32. Liu, Y.Z.; Hu, X.B. Segregation and microstructural evolution at interfaces of atmospheric plasma sprayed thermal barrier coatings during thermal cycling. J. Alloy. Compd. 2020, 819, 13. [CrossRef]

33. Yu, Q.M.; Zhou, H.L.; Wang, L.B. Influences of interface morphology and thermally grown oxide thickness on residual stress distribution in thermal barrier coating system. Ceram. Int. 2016, 42, 8338-8350. [CrossRef]

34. Balint, D.S.; Hutchinson, J.W. An analytical model of rumpling in thermal barrier coatings. J. Mech. Phys. Solids 2005, 53, 949-973. [CrossRef]

35. Karlsson, A.M.; Hutchinson, J.W.; Evans, A.G. A fundamental model of cyclic instabilities in thermal barrier systems. J. Mech. Phys. Solids 2002, 50, 1565-1589. [CrossRef] 
36. Naumenko, D.; Shemet, V.; Singheiser, L.; Quadakkers, W.J. Failure mechanisms of thermal barrier coatings on MCrAlY-type bondcoats associated with the formation of the thermally grown oxide. J. Mater. Sci. 2009, 44, 1687-1703. [CrossRef]

37. Rabiei, A.; Evans, A.G. Failure mechanisms associated with the thermally grown oxide in plasma-sprayed thermal barrier coatings. Acta Mater. 2000, 48, 3963-3976. [CrossRef]

38. Chen, W.R.; Wu, X.; Marple, B.R.; Nagy, D.R.; Patnaik, P.C. TGO growth behaviour in TBCs with APS and HVOF bond coats. Surf. Coat. Technol. 2008, 202, 2677-2683. [CrossRef]

39. Tang, J.J.; Bai, Y.; Liu, K.; Zhang, P.; Li, B.Q.; Yang, J.F. Microstructural evolution of SAPS/HVOF CoNiCrAlY alloy coating during thermal cycling test. Oxid. Met. 2016, 86, 75-87. [CrossRef]

40. Hutchinson, J.W.; He, M.Y.; Evans, A.G. The influence of imperfections on the nucleation and propagation of buckling driven delaminations. J. Mech. Phys. Solids 2000, 48, 709-734. [CrossRef]

41. Evans, A.G.; Mumm, D.R.; Hutchinson, J.W.; Meier, G.H.; Pettit, F.S. Mechanisms controlling the durability of thermal barrier coatings. Prog. Mater. Sci. 2001, 46, 505-553. [CrossRef]

42. Mumm, D.R.; Evans, A.G.; Spitsberg, I.T. Characterization of a cyclic displacement instability for a thermally grown oxide in a thermal barrier system. Acta Mater. 2001, 49, 2329-2340. [CrossRef]

43. He, M.Y.; Hutchinson, J.W.; Evans, A.G. Simulation of stresses and delamination in a plasma-sprayed thermal barrier system upon thermal cycling. Mater. Sci. Eng. A-Struct. Mater. Prop. Microstruct. Process. 2003, 345, 172-178. [CrossRef]

44. Tolpygo, V.K.; Clarke, D.R. Surface rumpling of a (Ni, Pt)Al bond coat induced by cyclic oxidation. Acta Mater. 2000, 48, 3283-3293. [CrossRef]

45. Tolpygo, V.K.; Clarke, D.R. Wrinkling of alpha-alumina films grown by thermal oxidation-I. Quantitative studies on single crystals of Fe-Cr-Al alloy. Acta Mater. 1998, 46, 5153-5166. [CrossRef]

46. Su, L.; Zhang, W.; Sun, Y.; Wang, T.J. Effect of TGO creep on top-coat cracking induced by cyclic displacement instability in a thermal barrier coating system. Surf. Coat. Technol. 2014, 254, 410-417. [CrossRef]

47. Song, J.N.; Li, S.L.; Yang, X.G.; Qi, H.Y.; Shi, D.Q. Numerical investigation on the cracking behaviors of thermal barrier coating system under different thermal cycle loading waveforms. Surf. Coat. Technol. 2018, 349, 166-176. [CrossRef]

48. Jiang, J.S.; Zou, Z.H.; Wang, W.Z.; Zhao, X.F.; Liu, Y.Z.; Cao, Z.M. Effect of internal oxidation on the interfacial morphology and residual stress in air plasma sprayed thermal barrier coatings. Surf. Coat. Technol. 2018, 334, 215-226. [CrossRef]

49. Zhu, W.; Zhang, Z.B.; Yang, L.; Zhou, Y.C.; Wei, Y.G. Spallation of thermal barrier coatings with real thermally grown oxide morphology under thermal stress. Mater. Des. 2018, 146, 180-193. [CrossRef]

50. Wei, Z.Y.; Cai, H.N.; Li, C.J. Comprehensive dynamic failure mechanism of thermal barrier coatings based on a novel crack propagation and TGO growth coupling model. Ceram. Int. 2018, 44, 22556-22566. [CrossRef]

51. Han, Y.J.; Ye, F.X.; Lu, G.X.; Liu, C.; Hao, L.J. Residual stress evolution of thermally grown oxide in thermal barrier coatings deposited onto nickel-base superalloy and iron-base alloy with thermal exposure ageing. J. Alloy. Compd. 2014, 584, 19-27. [CrossRef]

52. Cen, L.; Qin, W.Y.; Yu, Q.M. Finite element analysis of interface undulation and interface delamination in the MCrAlY coating system under thermal cycling: Considering oxide thickness and top-coat effects. J. Therm. Spray Technol. 2020, 29, 597-610. [CrossRef]

53. Chen, Z.; Huang, H.M.; Zhao, K.; Jia, W.B.; Fang, L. Influence of inhomogeneous thermally grown oxide thickness on residual stress distribution in thermal barrier coating system. Ceram. Int. 2018, 44, 16937-16946. [CrossRef]

54. Chai, Y.J.; Lin, C.; Wang, X.; Li, Y.M. Study on Stress Development in the phase transition layer of thermal barrier coatings. Materials 2016, 9, 14. [CrossRef]

55. Chen, H.; Zhang, C.; Xuan, J.; Liu, B.; Yang, G.; Gao, Y.; Luo, H. Effect of TGO evolution and element diffusion on the life span of YSZ/Pt-Al and YSZ/NiCrAlY coatings at high temperature. Ceram. Int. 2020, 46, 813-823. [CrossRef]

56. Lin, C.; Li, Y.M. A coupled mechanical-chemical model for reflecting the influence of stress on oxidation reactions in thermal barrier coating. J. Appl. Phys. 2018, 123, 10. [CrossRef]

57. Liu, Y.Z.; Zheng, S.J.; Zhu, Y.L.; Wei, H.; Ma, X.L. Microstructural evolution at interfaces of thermal barrier coatings during isothermal oxidation. J. Eur. Ceram. Soc. 2016, 36, 1765-1774. [CrossRef] 
58. Shen, Q.; Yang, L.; Zhou, Y.C.; Wei, Y.G.; Wang, N.G. Models for predicting TGO growth to rough interface in TBCs. Surf. Coat. Technol. 2017, 325, 219-228. [CrossRef]

59. Sun, Y.L.; Zhang, W.X.; Li, J.G.; Wang, T.J. Local stress around cap-like portions of anisotropically and nonuniformly grown oxide layer in thermal barrier coating system. J. Mater. Sci. 2013, 48, 5962-5982. [CrossRef]

60. Zhao, X.; Hashimoto, T.; Xiao, P. Effect of the top coat on the phase transformation of thermally grown oxide in thermal barrier coatings. Scr. Mater. 2006, 55, 1051-1054. [CrossRef]

61. Evans, A.G.; He, M.Y.; Hutchinson, J.W. Mechanics-based scaling laws for the durability of thermal barrier coatings. Prog. Mater. Sci. 2001, 46, 249-271. [CrossRef]

62. Clarke, D.R. The lateral growth strain accompanying the formation of a thermally grown oxide. Acta Mater. 2003, 51, 1393-1407. [CrossRef]

63. Sun, Y.; Li, J.; Zhang, W.; Wang, T.J. Local stress evolution in thermal barrier coating system during isothermal growth of irregular oxide layer. Surf. Coat. Technol. 2013, 216, 237-250. [CrossRef]

64. Lin, C.; Li, Y.M. Interface stress evolution considering the combined creep-plastic behavior in thermal barrier coatings. Mater. Des. 2016, 89, 245-254. [CrossRef]

65. Shen, Q.; Yang, L.; Zhou, Y.C.; Wei, Y.G.; Zhu, W. Effects of growth stress in finite-deformation thermally grown oxide on failure mechanism of thermal barrier coatings. Mech. Mater. 2017, 114, 228-242. [CrossRef]

66. Chai, Y.; Yang, X.; Li, Y.; Ogawa, K. Stress development in thermal barrier coatings with morphology-controlled thermally grown oxide. Ceram. Int. 2019, 45, 20435-20445. [CrossRef]

67. Loeffel, K.; Anand, L. A chemo-thermo-mechanically coupled theory for elastic-viscoplastic deformation, diffusion, and volumetric swelling due to a chemical reaction. Int. J. Plast. 2011, 27, 1409-1431. [CrossRef]

68. Loeffel, K.; Anand, L.; Gasem, Z.M. On modeling the oxidation of high-temperature alloys. Acta Mater. 2013, 61, 399-424. [CrossRef]

69. Lv, B.W.; Xie, H.; Xu, R.; Fan, X.L.; Zhang, W.X.; Wang, T.J. Effects of sintering and mixed oxide growth on the interface cracking of air-plasma-sprayed thermal barrier coating system at high temperature. Appl. Surf. Sci. 2016, 360, 461-469. [CrossRef]

70. Dong, H.; Yang, G.; Luo, X.; Li, C. Effects of mixed oxides on thermal cyclic lifetime of plasma-sprayed thermal barrier coatings. China Surf. Eng. 2015, 28, 21-28.

71. Yang, G.J.; Xiang, X.D.; Xing, L.K.; Li, D.J.; Li, C.J.; Li, C.X. Isothermal oxidation behavior of NiCoCrAlTaY coating deposited by high velocity air-fuel spraying. J. Therm. Spray Technol. 2012, 21, 391-399. [CrossRef]

72. Busso, E.P.; Evans, H.E.; Qian, Z.Q.; Taylor, M.P. Effects of breakaway oxidation on local stresses in thermal barrier coatings. Acta Mater. 2010, 58, 1242-1251. [CrossRef]

73. Li, Y.; Li, C.J.; Zhang, Q.; Yang, G.J.; Li, C.X. Influence of TGO Composition on the thermal shock lifetime of thermal barrier coatings with cold-sprayed MCrAlY bond coat. J. Therm. Spray Technol. 2010, 19, 168-177. [CrossRef]

74. Zhang, W.X.; Sun, Y.L.; Wang, T.J. Effect of spinel growth on the delamination of thermal barrier coatings. Key Eng. Mater. 2011, 462-463, 389-394. [CrossRef]

75. Xu, R.; Fan, X.L.; Zhang, W.X.; Wang, T.J. Interfacial fracture mechanism associated with mixed oxides growth in thermal barrier coating system. Surf. Coat. Technol. 2014, 253, 139-147. [CrossRef]

76. Zhang, B.Y.; Shi, J.; Yang, G.J.; Li, C.X.; Li, C.J. Healing of the interface between splashed particles and underlying bulk coating and its influence on isothermal oxidation behavior of LPPS MCrAlY bond coat. J. Therm. Spray Technol. 2015, 24, 611-621. [CrossRef]

77. Tang, J.J.; Bai, Y.; Zhang, J.C.; Liu, K.; Liu, X.Y.; Zhang, P.; Wang, Y.; Zhang, L.; Liang, G.Y.; Gao, Y.; et al. Microstructural design and oxidation resistance of CoNiCrAlY alloy coatings in thermal barrier coating system. J. Alloy. Compd. 2016, 688, 729-741. [CrossRef]

78. Bai, Y.; Ding, C.H.; Li, H.Q.; Han, Z.H.; Ding, B.J.; Wang, T.J.; Yu, L. Isothermal oxidation behavior of supersonic atmospheric plasma-sprayed thermal barrier coating system. J. Therm. Spray Technol. 2013, 22, 1201-1209. [CrossRef]

79. Lim, L.Y.; Meguid, S.A. Modeling and characterisation of depletion of aluminium in bond coat and growth of mixed oxides in thermal barrier coatings. Int. J. Mech. Mater. Des. 2019, 1-17. [CrossRef] 
80. Mahalingam, S.; Yunus, S.M.; Manap, A.; Afandi, N.M.; Zainuddin, R.A.; Kadir, N.F. Crack propagation and effect of mixed oxides on TGO growth in thick La-Gd-YSZ thermal barrier coating. Coatings 2019, 9, 719. [CrossRef]

81. Xie, F.; Zhang, W.X.; Li, H.M.; Fan, X.L. Modelling of alloying process of cold sprayed Ni/Al coating. Mech. Mater. 2019, 135, 129-143. [CrossRef]

82. Evans, A.G.; Clarke, D.R.; Levi, C.G. The influence of oxides on the performance of advanced gas turbines. J. Eur. Ceram. Soc. 2008, 28, 1405-1419. [CrossRef]

83. Elsass, M.; Frommherz, M.; Scholz, A.; Oechsner, M. Interdiffusion in MCrAlY coated nickel-base superalloys. Surf. Coat. Technol. 2016, 307, 565-573. [CrossRef]

84. Zhao, G.; Xu, B.; Ren, K.; Shao, G.; Wang, Y. Oxygen diffusion through environmental barrier coating materials. Ceram. Int. 2020, 46, 19545-19549. [CrossRef]

85. Fick, A.V. On liquid diffusion. Lond. Edinb. Dublin Philos. Mag. J. Sci. 1855, 10, 30-39. [CrossRef]

86. Darken, L.S. Diffusion of carbon in austenite with a discontinuity in composition. Trans. Am. Inst. Min. Metall. Eng. 1949, 180, 430-438.

87. Darken, L.S. Diffusion, mobility and their interrelation through free energy in binary metallic systems. Trans. Am. Inst. Min. Metall. Eng. 1948, 175, 184-201.

88. Yang, F.Q. Interaction between diffusion and chemical stresses. Mater. Sci. Eng. A-Struct. Mater. Prop. Microstruct. Process. 2005, 409, 153-159. [CrossRef]

89. Wang, W.L.; Lee, S.; Chen, J.R. Effect of chemical stress on diffusion in a hollow cylinder. J. Appl. Phys. 2002, 91, 9584-9590. [CrossRef]

90. Zhang, X.C.; Shyy, W.; Sastry, A.M. Numerical simulation of intercalation-induced stress in Li-ion battery electrode particles. J. Electrochem. Soc. 2007, 154, A910-A916. [CrossRef]

91. Suo, Y.H.; Shen, S.P. Coupling diffusion-reaction-mechanics model for oxidation. Acta Mech. 2015, 226, 3375-3386. [CrossRef]

92. Wang, X.K.; Fan, X.L.; Sun, Y.L.; Xu, R.; Jiang, P. Modelling and analysis of the oxide growth coupling behaviour of thermal barrier coatings. J. Mater. Sci. 2019, 54, 10270-10283. [CrossRef]

93. Haftbaradaran, H.; Song, J.; Curtin, W.A.; Gao, H.J. Continuum and atomistic models of strongly coupled diffusion, stress, and solute concentration. J. Power Sources 2011, 196, 361-370. [CrossRef]

94. Dong, X.L.; Fang, X.F.; Feng, X.; Hwang, K.C. Diffusion and stress coupling effect during oxidation at high temperature. J. Am. Ceram. Soc. 2013, 96, 44-46. [CrossRef]

95. Fang, X.F.; Li, Y.; Yue, M.K.; Feng, X. Chemo-mechanical coupling effect on high temperature oxidation: A review. Sci. China-Technol. Sci. 2019, 62, 1297-1321. [CrossRef]

96. Suo, Z. A continuum theory that couples creep and self-diffusion. J. Appl. Mech.-Trans. ASME 2004, 71, 646-651. [CrossRef]

97. Gao, Y.F.; Cho, M.; Zhou, M. Stress relaxation through interdiffusion in amorphous lithium alloy electrodes. J. Mech. Phys. Solids 2013, 61, 579-596. [CrossRef]

98. Sethuraman, V.A.; Chon, M.J.; Shimshak, M.; Van Winkle, N.; Guduru, P.R. In situ measurement of biaxial modulus of Si anode for Li-ion batteries. Electrochem. Commun. 2010, 12, 1614-1617. [CrossRef]

99. Sethuraman, V.A.; Chon, M.J.; Shimshak, M.; Srinivasan, V.; Guduru, P.R. In situ measurements of stress evolution in silicon thin films during electrochemical lithiation and delithiation. J. Power Sources 2010, 195, 5062-5066. [CrossRef]

100. Brassart, L.; Suo, Z.G. Reactive flow in solids. J. Mech. Phys. Solids 2013, 61, 61-77. [CrossRef]

101. Huang, S.; Fan, F.; Li, J.; Zhang, S.; Zhu, T. Stress generation during lithiation of high-capacity electrode particles in lithium ion batteries. Acta Mater. 2013, 61, 4354-4364. [CrossRef]

102. Bower, A.F.; Guduru, P.R.; Sethuraman, V.A. A finite strain model of stress, diffusion, plastic flow, and electrochemical reactions in a lithium-ion half-cell. J. Mech. Phys. Solids 2011, 59, 804-828. [CrossRef]

103. Zhao, K.J.; Pharr, M.; Cai, S.Q.; Vlassak, J.J.; Suo, Z.G. Large Plastic Deformation in high-capacity lithium-ion batteries caused by charge and discharge. J. Am. Ceram. Soc. 2011, 94, S226-S235. [CrossRef]

104. Zhao, K.J.; Pharr, M.; Wan, Q.; Wang, W.L.; Kaxiras, E.; Vlassak, J.J.; Suo, Z.G. Concurrent reaction and plasticity during initial lithiation of crystalline silicon in lithium-ion batteries. J. Electrochem. Soc. 2012, 159, A238-A243. [CrossRef] 
105. Zhao, K.J.; Tritsaris, G.A.; Pharr, M.; Wang, W.L.; Okeke, O.; Suo, Z.G.; Vlassak, J.J.; Kaxiras, E. Reactive flow in silicon electrodes assisted by the insertion of lithium. Nano Lett. 2012, 12, 4397-4403. [CrossRef] [PubMed]

106. Di Leo, C.V.; Rejovitzky, E.; Anand, L. Diffusion-deformation theory for amorphous silicon anodes: The role of plastic deformation on electrochemical performance. Int. J. Solids Struct. 2015, 67-68, 283-296. [CrossRef]

107. Moon, J.; Cho, K.; Cho, M. Ab-initio study of silicon and tin as a negative electrode materials for lithium-ion batteries. Int. J. Precis. Eng. Manuf. 2012, 13, 1191-1197. [CrossRef]

108. Yang, F.Q. Diffusion-induced stress in inhomogeneous materials: Concentration-dependent elastic modulus. Sci. China-Phys. Mech. Astron. 2012, 55, 955-962. [CrossRef]

109. Yang, F.Q. Entropy change-induced elastic softening of lithiated materials. Theor. Appl. Mech. Lett. 2015, 5, 255-257. [CrossRef]

110. Hong, C.S.; Qaiser, N.; Nam, H.G.; Han, S.M. Effect of Li concentration-dependent material properties on diffusion induced stresses of a Sn anode. Phys. Chem. Chem. Phys. 2019, 21, 9581-9589. [CrossRef]

111. Chang, S.; Moon, J.; Cho, M. Stress-diffusion coupled multiscale analysis of Si anode for Li-ion battery. J. Mech. Sci. Technol. 2015, 29, 4807-4816. [CrossRef]

112. Lu, Y.J.; Che, Q.; Song, X.; Wang, F.H.; Zhao, X. Stress self-relaxation arising from diffusion-induced creep in bilayer lithium-ion battery electrode. Scr. Mater. 2018, 150, 164-167. [CrossRef]

113. Xu, C.Q.; Deng, Q.F.; Weng, Z.D.; Chen, B.B.; Zhou, J.Q. Lithium-assisted creep deformation behavior of Sn nanoparticle electrode with fracture-resistant ability. J. Mater. Res. 2019, 34, 3887-3898. [CrossRef]

114. Pinson, M.B.; Bazant, M.Z. Theory of SEI formation in rechargeable batteries: Capacity fade, accelerated aging and lifetime prediction. J. Electrochem. Soc. 2013, 160, A243-A250. [CrossRef]

115. Zhang, B.Y.; Meng, G.H.; Yang, G.J.; Li, C.X.; Li, C.J. Dependence of scale thickness on the breaking behavior of the initial oxide on plasma spray bond coat surface during vacuum pre-treatment. Appl. Surf. Sci. 2017, 397, 125-132. [CrossRef]

116. Li, N.W.; Yin, Y.X.; Yang, C.P.; Guo, Y.G. An artificial solid electrolyte interphase layer for stable lithium metal anodes. Adv. Mater. 2016, 28, 1853-1858. [CrossRef]

117. Liu, Y.Y.; Lin, D.C.; Yuen, P.Y.; Liu, K.; Xie, J.; Dauskardt, R.H.; Cui, Y. An artificial solid electrolyte interphase with high Li-ion conductivity, mechanical strength, and flexibility for stable lithium metal anodes. Adv. Mater. 2017, 29, 8. [CrossRef]

118. De la Hoz, J.M.M.; Soto, F.A.; Balbuena, P.B. Effect of the electrolyte composition on SEI reactions at Si anodes of Li-ion batteries. J. Phys. Chem. C 2015, 119, 7060-7068. [CrossRef]

119. Hu, Z.L.; Zhang, S.; Dong, S.M.; Li, W.J.; Li, H.; Cui, G.L.; Chen, L.Q. Poly(ethyl alpha-cyanoacrylate)-based artificial solid electrolyte interphase layer for enhanced interface stability of Li metal anodes. Chem. Mat. 2017, 29, 4682-4689. [CrossRef]

120. Khorramirad, M.M.; Rahimipour, M.R.; Hadavi, S.M.M.; Shirvani, K. Preoxidation of bond coat in IN-738LC/NiCrAlY/LaMgAl ${ }_{11} \mathrm{O}_{19}$ thermal barrier coating system. Ceram. Int. 2018, 44, 22080-22091. [CrossRef]

121. Song, P.; Yu, X.; Huang, T.H.; He, X.; Ji, Q.; Zang, J.J.; Chen, R.; Lu, J.G.; Lu, J.S. Evolution of in-situ pores and high-temperature thermal-barrier performance of Al-Si coating on NiCoCrAl alloy. Surf. Coat. Technol. 2018, 344, 489-498. [CrossRef]

122. Wang, J.L.; Chen, M.H.; Yang, L.L.; Zhu, S.L.; Wang, F.H. Comparative study of oxidation and interdiffusion behavior of AIP NiCrAlY and sputtered nanocrystalline coatings on a nickel-based single-crystal superalloy. Corros. Sci. 2015, 98, 530-540. [CrossRef]

123. Wang, R.L.; Gong, X.Y.; Peng, H.; Ma, Y.; Guo, H.B. Interdiffusion behavior between NiAlHf coating and Ni-based single crystal superalloy with different crystal orientations. Appl. Surf. Sci. 2015, 326, 124-130. [CrossRef]

124. Wen, J.X.; Cao, R.; Gao, Y.F. Mysterious failure in load-free superalloys under repeated thermal shocks. Acta Mater. 2020, 194, 276-282. [CrossRef]

125. Yang, L.L.; Chen, M.H.; Wang, J.L.; Qiao, Y.X.; Guo, P.Y.; Zhu, S.L.; Wang, F.H. Microstructure and composition evolution of a single-crystal superalloy caused by elements interdiffusion with an overlay NiCrAlY coating on oxidation. J. Mater. Sci. Technol. 2020, 45, 49-58. [CrossRef]

126. Smigelskas, A.D.; Kirkendall, E.O. Zinc diffusion in alpha-brass. Trans. Am. Inst. Min. Metall. Eng. 1947, 171, 130-142. 
127. Texier, D.; Monceau, D.; Hervier, Z.; Andrieu, E. Effect of interdiffusion on mechanical and thermal expansion properties at high temperature of a MCrAlY coated Ni-based superalloy. Surf. Coat. Technol. 2016, 307, 81-90. [CrossRef]

128. Qi, W.Y.; Peng, H.; He, J.; Li, S.S.; Gong, S.K.; Guo, H.B. Cyclic oxidation and interdiffusion behavior of Pt modified NiAlHfCrSi coatings on single crystal superalloy containing Mo. Surf. Coat. Technol. 2014, 259, 426-433. [CrossRef]

Publisher's Note: MDPI stays neutral with regard to jurisdictional claims in published maps and institutional affiliations.

(C) 2020 by the authors. Licensee MDPI, Basel, Switzerland. This article is an open access article distributed under the terms and conditions of the Creative Commons Attribution (CC BY) license (http://creativecommons.org/licenses/by/4.0/). 